\title{
20. OXYGEN AND CARBON ISOTOPE ANALYSES OF CRETACEOUS AND TERTIARY FORAMINIFERA FROM THE CENTRAL NORTH PACIFIC ${ }^{1}$
}

\author{
Robert G. Douglas and Samuel M. Savin, Department of Geology, Case Western Reserve University, Cleveland, Ohio
}

\section{INTRODUCTION}

Oxygen and carbon isotope analyses of Cenozoic and Cretaceous foraminifera from two Leg 17 sites, 167 and 171 , were performed. Analyses were made of mixed species of planktonic foraminifera, mixed species of benthonic foraminifera, a small number of individual species of planktonic foraminifera, and some limestone samples from Site 167.

The two sites were selected for study because the cores provide good stratigraphic coverage, the ocean bottom at each coring site is at a depth considerably shallower than the calcium carbonate compensation depth, resulting in abundant and generally well-preserved foraminifera, and the two sites provide a latitudinal spread of $12^{\circ}$. Sample locations are shown in Figure 1.

Site $167\left(7^{\circ} 04.1^{\prime} \mathrm{N}, 167^{\circ} 49.5^{\prime} \mathrm{W}\right)$ is located near the crest of the Magellan Rise in 3,176 meters of water. The sedimentary section is 1,172 meters thick and consists of five stratigraphic units: (1) Quaternary to lower Miocene ooze $(220 \mathrm{~m})$; (2) Oligocene to late Eocene ooze and chalk (380 m); (3) Middle Eocene to lower Paleocene cherty chalk (147 m); (4) Maestrichtian to Campanian cherty chalk (147 m); and (5) Coniacian to Tithonian cherty limestone $(345 \mathrm{~m})$. Details of the lithology and stratigraphy are discussed in Chapter 5.

Site $171\left(19^{\circ} 07.8^{\prime} \mathrm{N}, 169^{\circ} 27.6^{\prime} \mathrm{W}\right)$ is located in a saddle on Horizon Guyot in 2,283 meters of water. The site is 56 $\mathrm{km}$ south and west of Site 44 of Leg 6, from which foraminifera have previously been isotopically analyzed (Douglas and Savin, 1971). The section consists of 143 meters of Quaternary to middle Eocene ooze, resting with erosional unconformity on 351 meters of Maastrichtian to Cenomanian cherty chalk, volcanic sediment, and detrital limestone which contains shallow-water fossils. Details of the lithology and stratigraphy are discussed in Chapter 9.

Samples for isotopic analysis were chosen from levels where the microfauna is well preserved, the foraminifera are sufficiently abundant for analysis, and the zonal stratigraphy is well-defined. Wherever possible, samples from the same foraminiferal zone or adjacent zones from both sites were analyzed to permit direct comparison. This was possible for the early Pleistocene, early Miocene, Oligocene, middle and late Eocene, and Maastrichtian. Sample intervals and paleontological zones are shown in Table 1. Samples from Site 171 were also chosen from the same levels as foraminifera previously studied at nearby Site 44 in order to check our methods and results and to test for post-

\footnotetext{
${ }^{1}$ Contribution No. 99 of the Department of Geology, Case Western Reserve Univversity.
}

depositional isotopic exchange. Correlation of the zones and their approximate geochronology is based on the work of Berggren $(1969,1972)$.

In all, 83 foraminiferal samples and 8 bulk limestone samples were analyzed. These range in age from Pleistocene to Berriasian-Tithonian. A preliminary discussion of our results is given here, and a more complete discussion will appear elsewhere. Isotopic paleotemperatures have been used to test models of Pacific plate motion and to reconstruct paleotemperature curves for near-surface and bottom water in the Pacific Ocean from the late Cretaceous to the Pleistocene.

\section{SAMPLE PREPARATION}

The methods of preparation and analysis of the foraminifera are identical to those described by Douglas and Savin (1971). Assemblages of mixed species of benthonic foraminifera were hand-picked from the coarser-than- $150 \mu$ fraction of the samples. Because benthonic foraminifera normally comprise less than 0.5 percent of the foraminiferal assemblage in deep-sea sediments, it was necessary in some cases to combine several samples in order to obtain enough specimens for analysis. Only calcareous species with secreted (not agglutinated) shells were analyzed. Wholerock analyses of limestones were made on deeper cores from Site 167, using crushed pieces of limestone which were first cleaned in an ultrasonic bath.

The microfossils were analyzed isotopically, using standard techniques (Epstein et al., 1959), after crushing, washing, and treating with sodium hypochlorite (Clorox). All results are reported in $\delta$ notation as per mil deviations from the PDB-1 standard. Precision of the analyses is generally better than 0.1 per mil. Temperatures were calculated using the equation of Craig (1965) and the assumption that the isotopic composition of sea water in which the planktonic foraminiferal shells grew was 0.00 per mil relative to Standard Mean Ocean Water (SMOW) and the shells of the benthonic species grew in water with an $018 / 0^{16}$ ratio of -0.60 per mil relative to SMOW. Because of the uncertainties in the isotopic composition of seawater, the calculated temperatures at one or both sites may be systematically a few degrees higher or lower than actual growth temperatures for part or all of the time period studied.

\section{RESULTS}

The results for Sites 167 and 171, plotted against depth, are shown in Figures 2 and 3, respectively. The oxygen and carbon isotope ratios of samples of mixed species of planktonic and benthonic foraminifera are shown in Figures 4 and 5 . Several aspects of the data are discussed below. 


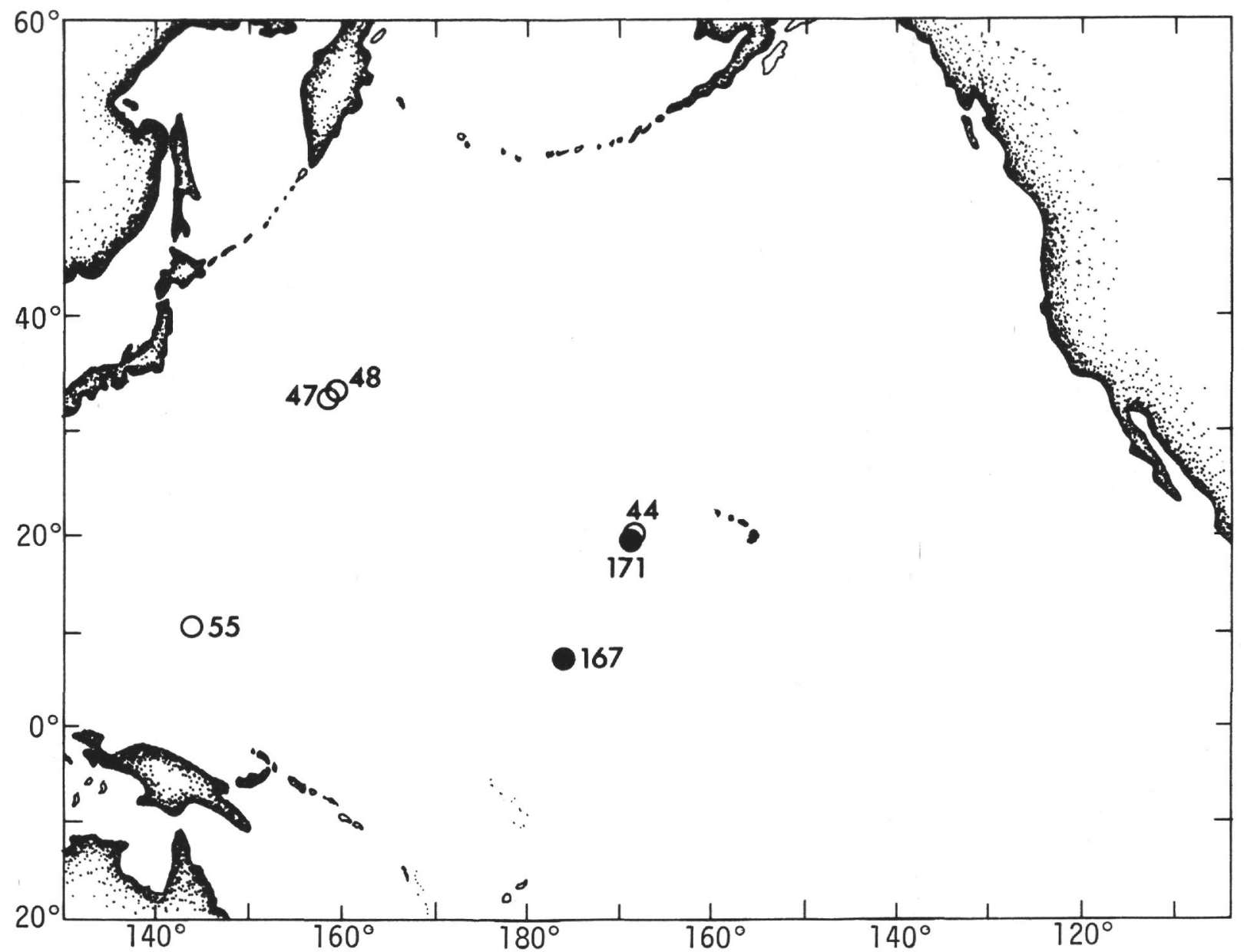

Figure 1. Location of DSDP sites from which foraminifera have been isotopically studied.

\section{Depth Stratification in Miocene Species}

Different species of planktonic foraminifera tend to live at different depths in the water column. The average depths at which various planktonic species live range from near the surface to several hundred meters. Oxygen isotope ratios of the calcite tests of different species from the same sediment assemblage yield isotopic temperatures which are assumed to reflect ambient temperatures at the average depths at which those species secreted their tests. Thus, in constructing paleoclimatic models from the isotopic data, it is necessary to know whether fossil species of planktonic foraminifera were depth stratified, and if so, what the depth habitats of different species were. It is this information that must be used in estimating surface water temperatures from the isotopic data. The same information is also of use in understanding the paleoecology and paleobiogeography of planktonic foraminifera.

As part of a larger study of depth stratification of planktonic foraminifera (Douglas and Savin, 1973), nine middle Miocene species from Core 5 of Site 167 were isotopically analyzed. The results indicate that Miocene species were temperature-stratified in a manner similar to Recent and Pleistocene species (Table 2). Species of Globigerinoides give the warmest temperatures; Orbulina universa, Sphaeroidinellopsis seminulina, and species of
Globigerina and Globoguadrina give intermediate temperatures; and Globorotalia fohsi gives the coldest temperature. Although most of these species are no longer extant, the ranking of the Miocene genera with respect to isotopic temperature is identical to temperature and depth rankings obtained both from plankton tow data (Berger, 1969) and from the 018/016 ratios of Recent sediment samples (Savin and Douglas, 1973). It seems evident then that Miocene planktonic foraminifera were stratified in the water column and that the depth rankings of genera have remained unchanged for the last 14 million years. In addition, Miocene species which are morphologically similar to present-day species have isotopic temperatures and, therefore, have depth rankings which are similar to those of their present-day counterparts (Table 2).

Depth stratification data can provide information about the thermal structure of the water column. The maximum temperature difference between growth habitats of the shallowest-dwelling and the deepest-dwelling planktonic species at a single location at the present time is around $10^{\circ}$ to $14^{\circ} \mathrm{C}$ and is found in low latitudes (Table 2). A difference of $7^{\circ} \mathrm{C}$ or $8^{\circ} \mathrm{C}$ is commonly found between the isotopic temperatures of G. ruber and Globorotalia tumida from Recent sediments. Our Miocene data indicate a temperature difference of only about $2.5^{\circ} \mathrm{C}$ between the 
TABLE 1

Sample Data, Paleontological Age, and Isotopic Results of Samples Analyzed

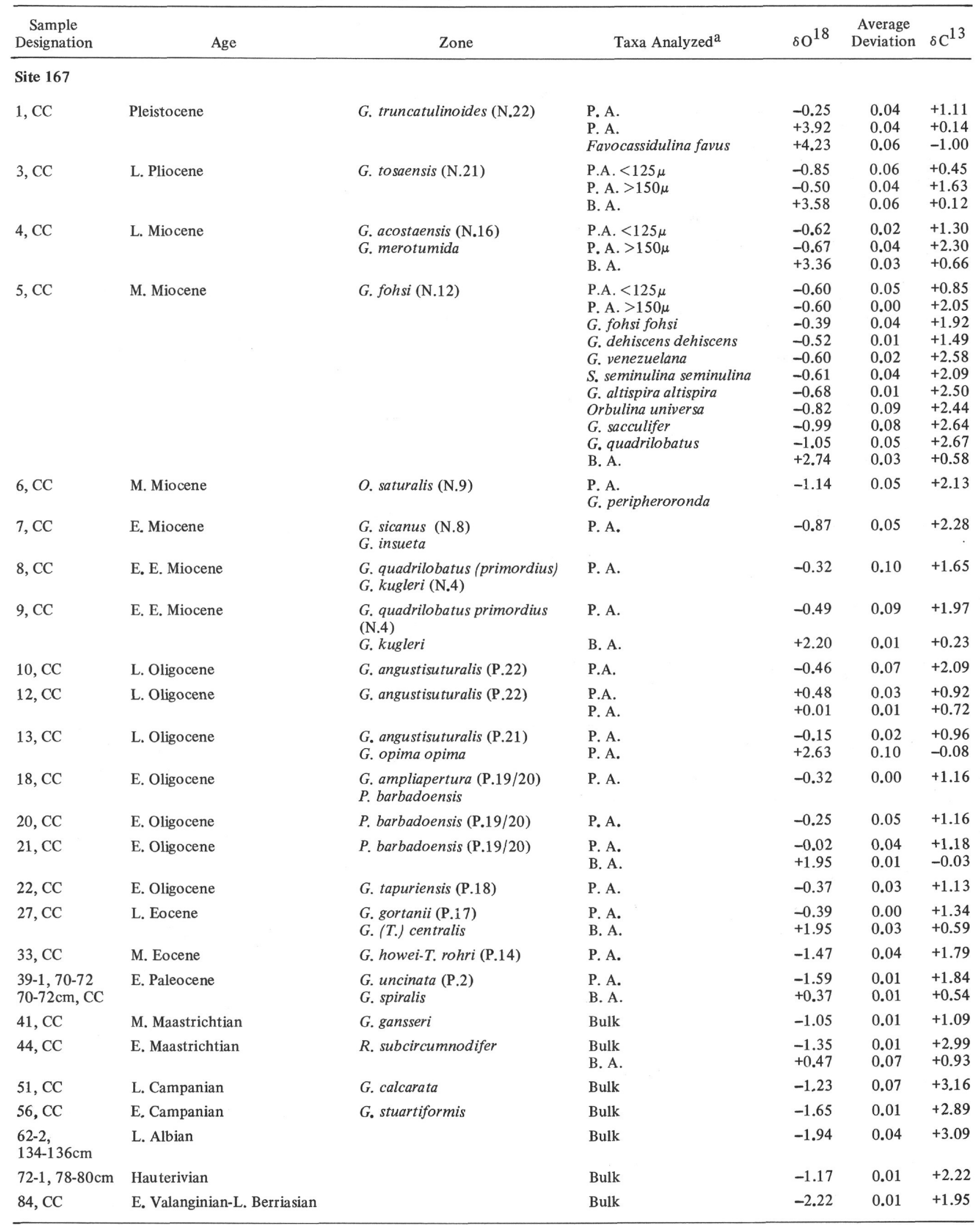


TABLE 1 - Continued

\begin{tabular}{|c|c|c|c|c|c|c|}
\hline $\begin{array}{l}\text { Sample } \\
\text { Designation }\end{array}$ & Age & Zone & Taxa Analyzed $^{\mathrm{a}}$ & $\delta \mathrm{O}^{18}$ & Average & $\delta \mathrm{C}^{13}$ \\
\hline \multicolumn{7}{|c|}{ Site 167 - Continued } \\
\hline $88, \mathrm{CC}$ & E. Valanginian-L. Berriasian & & Bulk & -2.33 & - & +1.68 \\
\hline $\begin{array}{l}93-1 \\
148-150 \mathrm{~cm}\end{array}$ & E. Valanginian-L. Berriasian & & Bulk & -2.88 & 0.08 & +1.72 \\
\hline \multicolumn{7}{|l|}{ Site 171} \\
\hline $\begin{array}{l}1, \mathrm{CC} \\
1-2,70-72 \mathrm{~cm}\end{array}$ & Quaternary & & $\begin{array}{l}\text { P. A. } \\
\text { B. A. }\end{array}$ & $\begin{array}{l}-0.35 \\
+3.25\end{array}$ & $\begin{array}{l}0.09 \\
0.03\end{array}$ & $\begin{array}{l}+1.76 \\
-0.63\end{array}$ \\
\hline $2, \mathrm{CC}$ & E. Miocene & $\begin{array}{l}\text { G. sicanus (N.8) } \\
\text { G. insueta }\end{array}$ & $\begin{array}{l}\text { P. A. } 125 \mu \\
\text { P. A. }>150 \mu\end{array}$ & -0.33 & - & +2.59 \\
\hline $5, \mathrm{CC}$ & L. Oligocene & $\begin{array}{l}\text { G. angustisuturalis }(\mathrm{P} .21) \\
\text { G. opima opima }\end{array}$ & P. A. & -0.58 & 0.10 & +1.28 \\
\hline $\begin{array}{l}5-6, \\
145-149 \mathrm{~cm}\end{array}$ & L. Oligocene & & B. A. & +2.40 & 0.00 & +0.15 \\
\hline $6, \mathrm{CC}$ & E. Oligocene & G. tapuriensis (P.18) & $\begin{array}{l}\text { P. A. } \\
\text { B. A. }\end{array}$ & $\begin{array}{l}+0.43 \\
+1.88\end{array}$ & $\begin{array}{l}0.04 \\
0.22\end{array}$ & $\begin{array}{l}+1.59 \\
+0.24\end{array}$ \\
\hline $8, \mathrm{CC}$ & M. Eocene & $\begin{array}{l}\text { O. beckmanni (P.13-P.12) } \\
\text { G. lehneri }\end{array}$ & $\begin{array}{l}\text { P. A. } \\
\text { B. A. }\end{array}$ & $\begin{array}{l}-0.88 \\
+0.71\end{array}$ & $\begin{array}{l}- \\
-\end{array}$ & $\begin{array}{l}+2.38 \\
+0.57\end{array}$ \\
\hline $9, \mathrm{CC}$ & L. Maastrichtian & A. mayaroensis & P. A. & -0.33 & 0.07 & +2.54 \\
\hline $18, \mathrm{CC}$ & E. Maastrichtian & & & -1.90 & 0.12 & +1.93 \\
\hline $20, \mathrm{CC}$ & L. Campanian & & P. A. & -1.32 & 0.11 & +2.15 \\
\hline $22, \mathrm{CC}$ & Coniacian & M. renzi & P. A. & -3.90 & 0.03 & +2.13 \\
\hline $23, \mathrm{CC}$ & & & P. A. & -2.54 & 0.00 & +1.66 \\
\hline $24, \mathrm{CC}$ & L. Turonian & $M$. helvetica & P. A. & -4.03 & - & +0.97 \\
\hline $26, \mathrm{CC}$ & E, Turonian & M. hagni & P. A. & -3.40 & 0.05 & +1.37 \\
\hline
\end{tabular}

${ }^{\mathrm{a}} \mathrm{P} . \mathrm{A} .=$ planktonic assemblage; $\mathrm{B} . \mathrm{A} .=$ benthonic assemblage. 


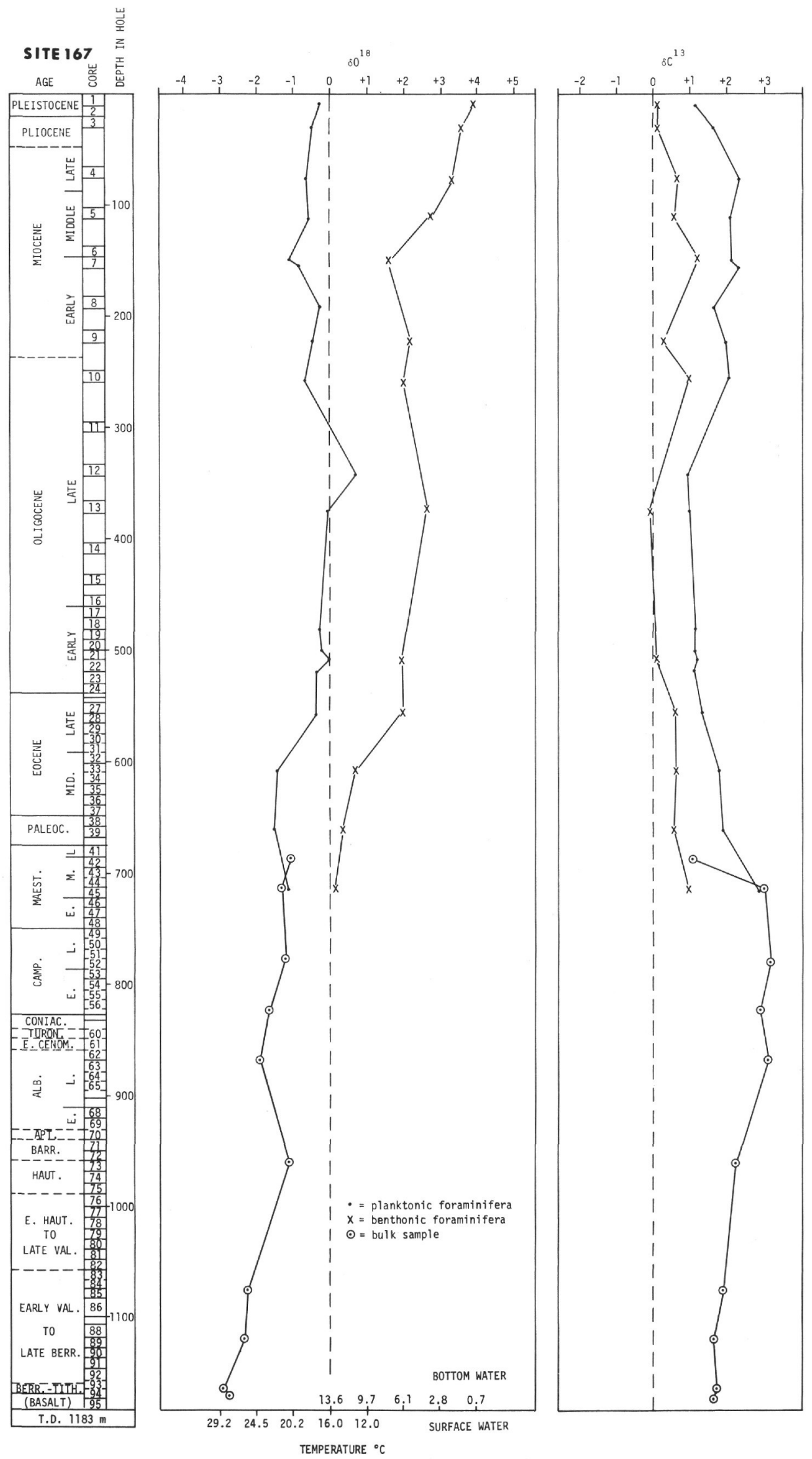

Figure 2. Isotopic results for Site 167 plotted against depth in hole. 


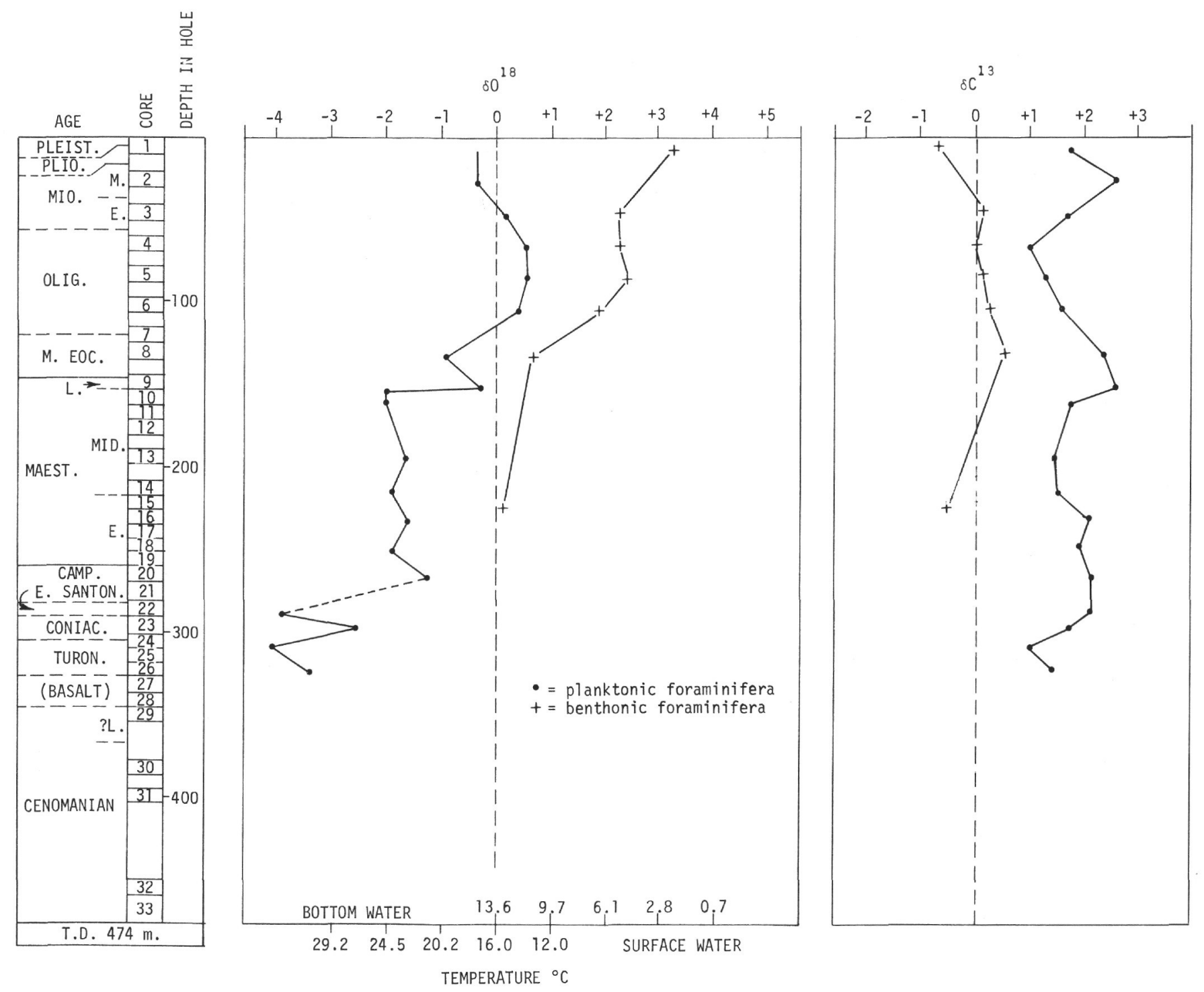

Figure 3. Isotopic results for Site 171 plotted against depth in hole. 


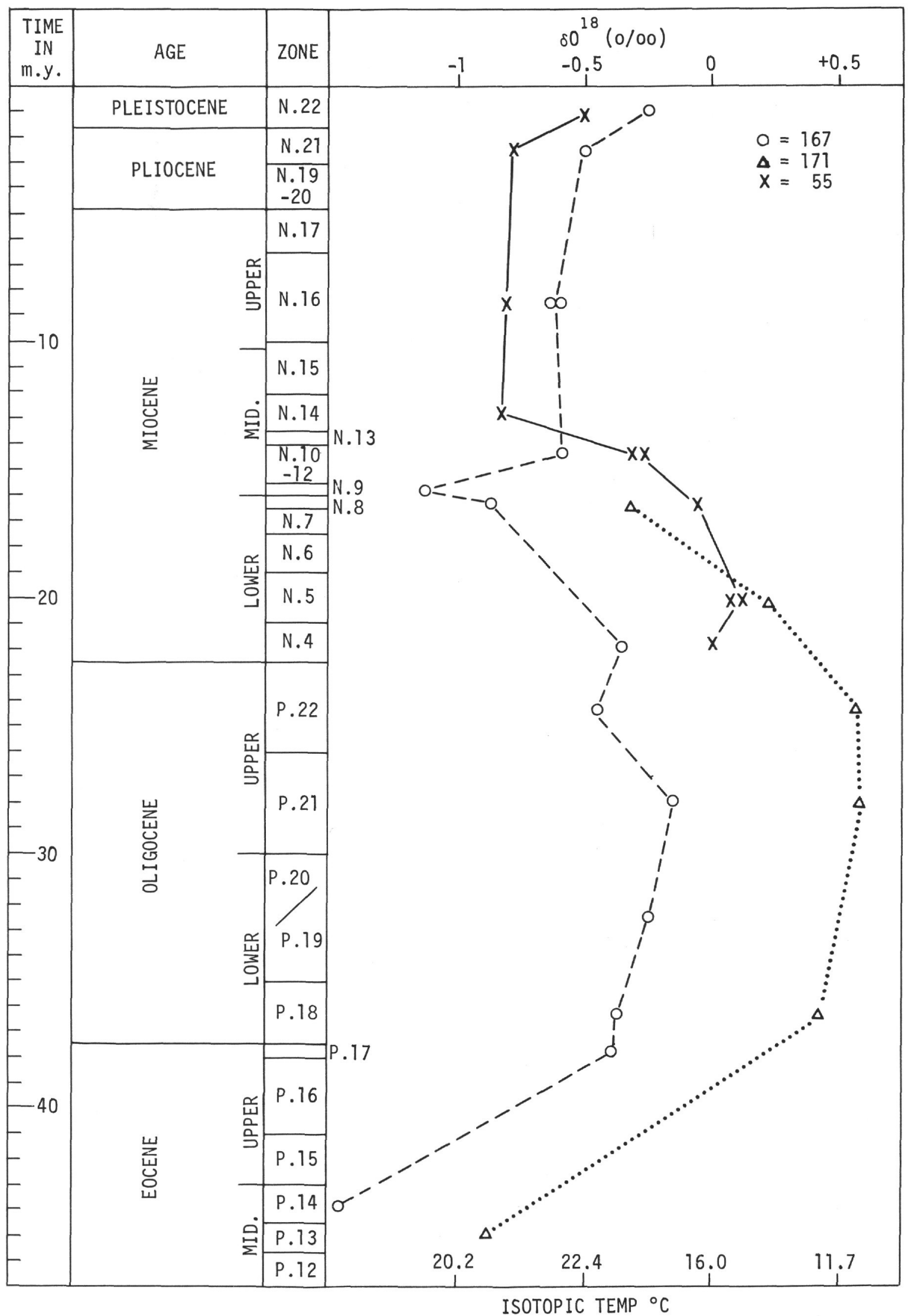

Figure 4. Comparison of Tertiary oxygen isotope ratios of planktonic assemblages from Sites 55, 167, and 171. 


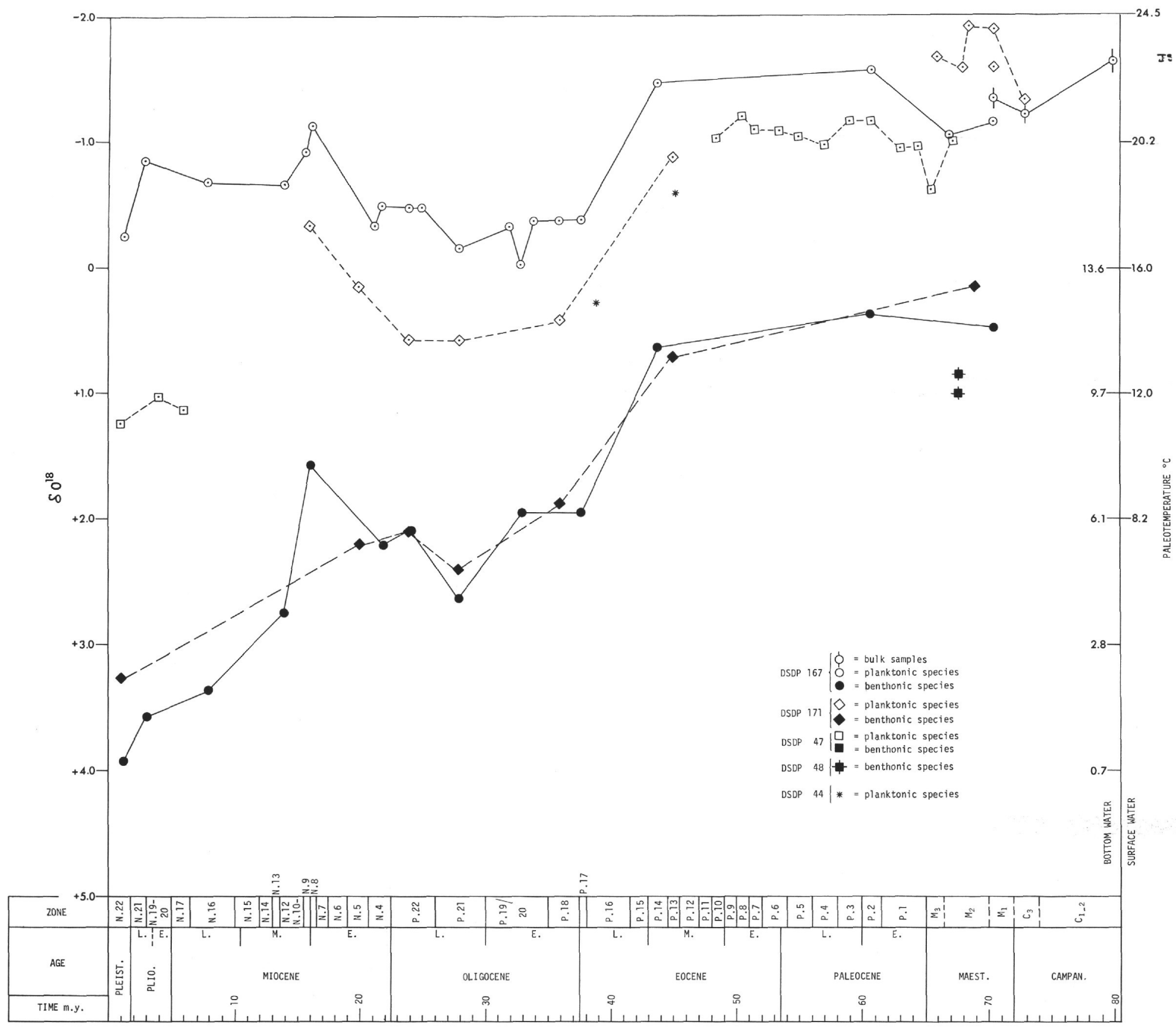

Figure 5. Comparison of isotopic results from Sites 44, 47, 48, 167, and 171. 
TABLE 2

Isotopic Paleotemperature Ranking of Selected Miocene Planktonic Foraminiferal Species, Compared to Recent Species

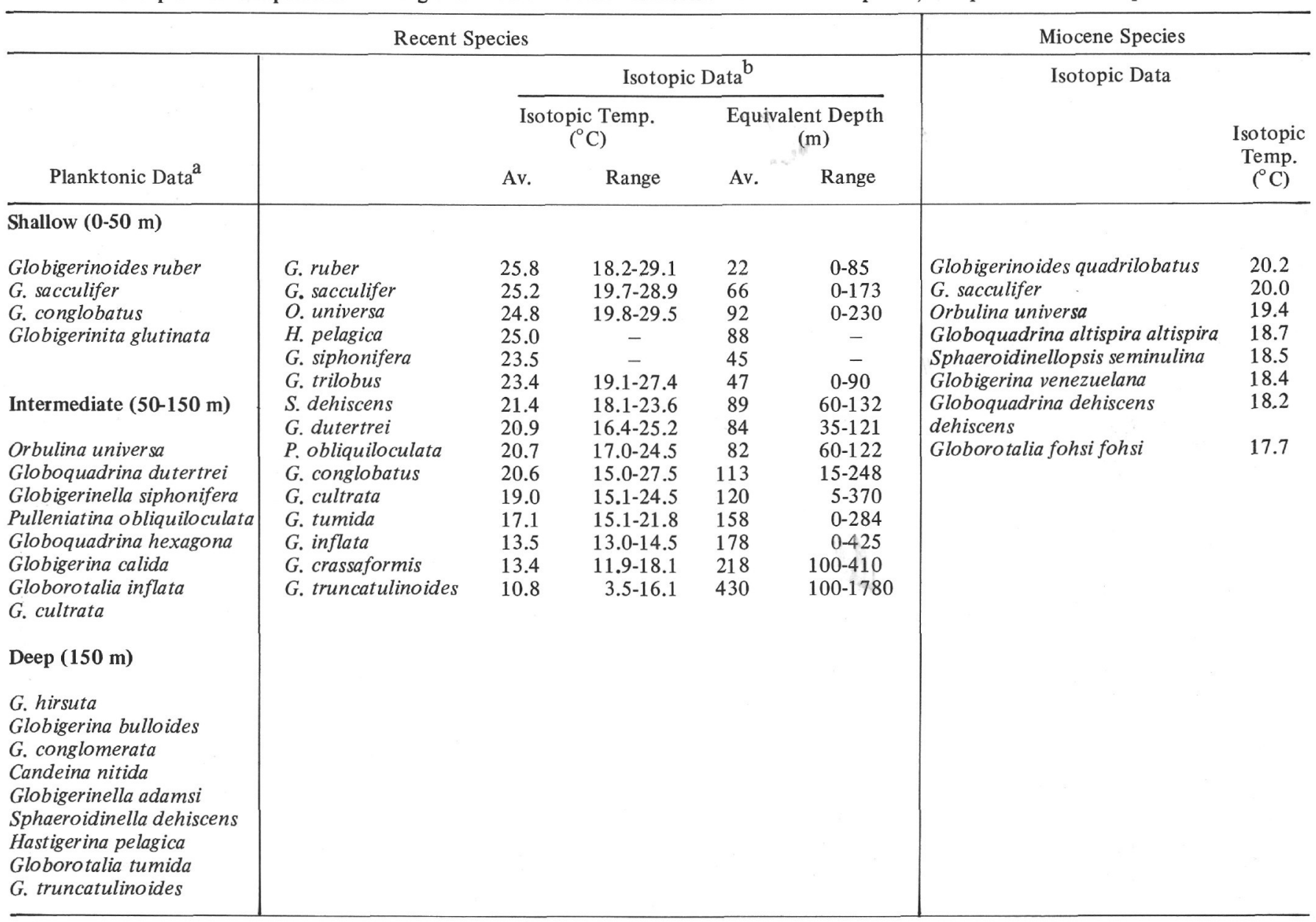

${ }^{a}$ Berger, 1970. Depth-rankings based on plankton tows. Species are approximately ordered within each category.

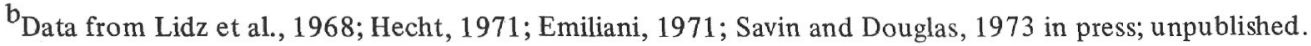

isotopic temperatures of Globigerinoides quadrilobatus (morphologically similar to G. ruber) and Globorotalia fohsi (morphologically similar to G. tumida). We believe that the greater difference between the isotopic temperatures of these shallow and deep-dwelling species in the Recent is indicative of a change in the thermal structure of the water column since the Miocene. Bottom temperatures in the middle Miocene were around $6^{\circ} \mathrm{C}$. The data suggest a vertical thermal gradient of $18^{\circ}$ to $20^{\circ} \mathrm{C}$ from surface to bottom in equatorial regions and a gradient of $5^{\circ}$ or $6^{\circ} \mathrm{C}$ in the upper few hundred meters of the ocean during the middle Miocene. The temperature gradient of the upper few hundred meters of the oceans in low latitudes thus appears to have become steeper by a factor of 2 or 3 in the last 14 million years.

\section{Paleotemperatures}

Paleotemperatures calculated from the $018 / 016$ ratios of mixed species assemblages of planktonic foraminifera can be used to estimate surface temperatures. However, such paleotemperatures are always lower than actual surface temperatures because of the distribution of growth habitats with depth in the upper few hundred meters of the water column and because of epigenetic and diagenetic selective dissolution which removes shallow-dwelling species more rapidly than deeper-dwelling species (Berger, 1971; Savin and Douglas, 1973). The isotopic temperature of a sample composed of many individuals of many species is a weighted average of the temperatures at which all the constituents of the assemblage secreted their tests. An estimate of the difference between actual surface temperature and the isotopic temperature derived from a mixed assemblage of planktonic foraminifera of late Neogene age can be estimated using data from a study of Recent sediment assemblages from the South Pacific (Savin and Douglas, 1973). Shallow-dwelling species (Globigerinoides ruber) from Recent sediments yield isotopic temperatures which are lower than actual surface temperature by an average of $4^{\circ} \mathrm{C}$, while deep-dwelling species (Globorotalia crassaformis, $G$. truncatulinoides) and mixed species assemblages yield isotopic temperatures which are on the average lower than surface temperatures by $8^{\circ} \mathrm{C}$ and $6^{\circ} \mathrm{C}$, respectively. For pre-Recent samples, it is not possible to estimate directly the difference between isotopic and surface temperatures. However, the lower value of the surface-to-bottom temperature gradient in the Paleogene 
and Cretaceous (Figure 5) suggests much smaller differences between surface temperatures and the isotopic temperatures of mixed planktonic assemblages at that time. The difference between the isotopic temperatures of shallow and deep-dwelling planktonic species from tropical regions averages $10^{\circ} \mathrm{C}$ for Recent sediment samples, but less than $5^{\circ} \mathrm{C}$ for the Miocene, $3^{\circ} \mathrm{C}$ for the middle Eocene, and $2^{\circ} \mathrm{C}$ for the Maastrichtian. Thus, the isotopic temperatures of assemblages of mixed species of planktonic foraminifera are probably within a few degrees of actual surface values in the pre-Neogene and within $6^{\circ} \mathrm{C}$ for the late Neogene. These estimates do not include correction for any variation in the isotopic composition of seawater, which may vary locally as current patterns and climate change, and on a worldwide scale since the late Miocene as a function of the growth and retreat of the polar ice caps.

There is growing evidence that benthonic foraminifera do not deposit their tests in isotopic equilibrium with the water in which they grow (Duplessy et al., 1970). Comparison of our own and published oxygen isotope analyses of Recent benthonic foraminifera with measured water temperatures at the locations in which they grew suggests that isotopic temperatures of mixed species assemblages of Recent benthonic foraminifera approximate growth temperatures. In interpreting our data from Sites 167 and 171 , we tentatively conclude that throughout the Tertiary, isotopic temperatures of mixed species assemblages of benthonic foraminifera also approximate growth temperatures.

Calcareous microfossils from the late Cretaceous at Site 167 above Core 56 exhibit some calcite overgrowth and cementation (see Schlanger, et al., this volume), but both the variation with time and values of the $018 / 0^{16}$ ratios of samples from Cores 41,44 , and 51 are consistent with data from samples of the same age from other sites in the Pacific and Atlantic (Douglas and Savin, 1973; Saito and Van Donk, 1971). Therefore, the $018 / 0^{16}$ ratios of the microfossils from these cores have not been extensively altered by the amount of calcite overgrowth which has occurred. In addition to the analyses of planktonic foraminifera from the Campanian and Maastrichtian of Site 167 , analyses were made of bulk limestone from the earlier Cretaceous material of this hole. The isotope ratios of these limestones have probably been altered by the diagenesis that has occurred below Core 56 and thus may not reflect the original oxygen isotope ratios of the samples.

The isotopic temperatures of planktonic foraminifera from Sites 167 and 171 describe two curves which are essentially parallel through the Tertiary (Figure 4). Samples from Site 167 give higher temperatures in the Tertiary, but in the Upper Cretaceous the difference between the two sets of data is much smaller and samples from Site 171 give higher temperatures (Figure 5). While the isotope data of the planktonic samples define a separate curve for each site, the isotope data of the benthonic assemblages from both sites lie along a single curve. This indicates that bottom water has had essentially the same temperature at both locations throughout the Tertiary and has presumably originated by the sinking of cold surface water in near-polar regions as it does at the present time. The basic features of the isotope data (and the temperatures inferred from them) are discussed below.

A temperature minimum in the Campanian was followed by an upturn in temperature values during the Maastrichtian (Figure 5). Between the latest Campanian and middle Maastrichtian the isotopic temperature increased by about $3^{\circ} \mathrm{C}$ at Site 171 and about $1.5^{\circ} \mathrm{C}$ at Site 167 . A middle Maastrichtian maximum can be identified in samples from Sites 47 and 48 from the Shatsky Rise (Douglas and Savin, 1973). These data indicate that there was a short-lived warming in the North Pacific in the latest Cretaceous Assemblages of benthonic foraminifera of early Maestrichtian age are enriched in 018 by 1.8 per mil relative to planktonic samples from Site 171. This corresponds to a temperature difference of about $8^{\circ} \mathrm{C}$ and suggests that the top-to-bottom temperature gradient in the Maastrichtian in low latitudes was about one-third of its present value. Data from the Shatsky Rise (Site 47) indicate a similar vertical temperature gradient at that time. The small difference in the Maastrichtian of $1.5^{\circ} \mathrm{C}$ between the isotopic temperatures of planktonic samples of Sites 167 and 47 (Figure 5), which are separated by $25^{\circ}$ of latitude, suggests that there was a small latitudinal temperature gradient compatible with the small vertical temperature gradient.

At the end of the Cretaceous both surface and bottom temperatures dropped, reaching a minimum near the Tertiary-Cretaceous boundary.

During the Tertiary, temperature maxima occurred in the early Paleogene and middle Miocene, and minima occurred in the late Eocene to Oligocene and late Neogene. Paleogene samples studied were limited to the early Paleocene and middle and late Eocene from Site 167 and to the middle and late Eocene from Site 171. Thus we cannot determine from these data exactly when in the Paleogene the highest temperatures were reached. However, the temperature trends inferred from the Leg 17 data are compatible with the Eocene and Paleocene temperatures of samples from the Shatsky Rise (Leg 6) (Douglas and Savin, 1971). These data indicate that there was a warm interval between the late Paleocene and the early Eocene (Figure 5). A steep temperature decline is evident during the middle and late Eocene. This was followed by a more gradual decline to a temperature minimum during the late Oligocene. The temperature drop from the late Eocene to the late Oligocene, as indicated by the $018 / 016$ ratios of the planktonic foraminifera, was $5.4^{\circ} \mathrm{C}$ at Site 167 , and isotopic temperatures reached a minimum of $16.6^{\circ} \mathrm{C}$ at this site. At Site 171 the isotopic temperature drop was $5.7^{\circ} \mathrm{C}$, and temperatures reached a minimum of $13.6^{\circ} \mathrm{C}$. The declines in surface temperature were paralleled by a drop in the bottom temperature from $13.2^{\circ} \mathrm{C}$ in the middle Eocene to around $7^{\circ} \mathrm{C}$ in the late Oligocene.

Temperatures increased in the early Miocene and the warmest temperatures measured for the Neogene at Sites 167 and 171 were obtained from samples of earliest middle Miocene age. However, in the western Pacific, in the Caroline Basin at Site 55, the highest temperatures were obtained from samples about 3 m.y. younger. Further work is necessary to determine whether this apparent discrepancy regarding the time of the Miocene temperature maximum is 
simply an artifact of the manner in which the samples were chosen or whether it is evidence of changing locations of ocean currents (or motion of the Pacific plate).

Following a period of fairly constant temperatures in the late Miocene, isotopic temperatures of planktonic foraminifera declined through the Pliocene and Pleistocene. However, bottom temperatures fall abruptly after the early middle Miocene temperature maximum. Our sample coverage of this interval is sparse and is insufficient to indicate any details of the complex climatic history of the interval. However, it is evident from our data that during the late Neogene there was a decrease in bottom temperatures and an increase in the vertical thermal gradient. In the early Miocene, the difference between surface and bottom water temperatures in the equatorial region was about $16^{\circ} \mathrm{C}$ (based on an estimated surface temperature of $24^{\circ} \mathrm{C}$ ), but this difference rapidly increased to greater than $25^{\circ} \mathrm{C}$ by the Pleistocene.

\section{Paleotemperature Test of Motion of the Pacific Plate}

A combination of paleomagnetic data, biogenous sediment distribution patterns, and paleontologic data suggests that the Pacific plate is moving both westward and northward with respect to the earth's spin axis.

Paleolatitudes derived from paleomagnetic studies of mid-Cretaceous volcanoes (Francheteau et al., 1970) and Cenomanian or Turonian sediment cores (Sclater and Jarrard, 1971) show a northward shift of the Pacific plate about $30^{\circ}$ latitude in the last $100 \mathrm{~m} . y$. Facies patterns and the thick bulge of biogenous sediment resulting from high productivity in the equatorial belt can be traced in seismic reflection surveys (Ewing et al., 1968) and drilling results (Winterer et al., 1971; Tracey et al., 1971; Hays et al., 1970; van Andel et al., 1971). These data show a northward shift of about $7^{\circ} \mathrm{C}$ in the past $30 \mathrm{~m} . \mathrm{y}$.

By assuming a northwestward motion of the Pacific plate with respect to the earth's spin axis (Claque and Jarrard, in press), we have calculated the latitudinal positions of Sites 167 and 171 at several times during the last 80 m.y. and plotted these paleolatitudes against the isotopic paleotemperatures recorded by the planktonic assemblages deposited at those times (Figure 6). According to the assumed model of plate motion, the two sites have moved from latitudes of about $20^{\circ} \mathrm{S}$ and $32^{\circ} \mathrm{S}$, respectively, 80 million years ago to their present locations at $7^{\circ} \mathrm{N}$ and $19^{\circ} \mathrm{N}$, respectively. If this model were correct, as the sites moved northward, the temperature history of each would have changed in a systematic fashion, warming as the site approached the equatorial zone and subsequently cooling as it crossed the thermal equator and moved northward away from it.

This test of plate motion is based on the assumption that the warmest surface temperatures are found at the geographic equator and that temperatures decrease symmetrically away from the equator. At the present time the thermal equator in the central Pacific Ocean is displaced about $4^{\circ}$ north of the geographic equator, and this may also have been so in the past. However, within the sensitivity of our method, such a displacement would not be evident. More important to the test is the consistency with which the isotopic temperatures obtained from mixed species assemblages of planktonic foraminifera of the same age but from different locations deviate from actual surface temperatures. We believe that at least prior to the sharp increase in vertical temperature gradients in the late Miocene, no circumstances existed which might have caused major inconsistencies in the differences between surface temperatures and isotopic temperatures as a function of latitude.

As can be seen in Figure 7, the isotopic data are in reasonable agreement with the results predicted from the plate motion model. According to this model, in the latest Cretaceous, Site 171 would have occupied a near-equatorial position and, as predicted, isotopic temperatures of samples from that site are higher than the isotopic temperatures of samples from Site 167. While the temperature difference between the two sites was negligible 74 million years ago, our other Maastrichtian data indicate that waters were warmer at Site 171 than at Site 167. All of our comparisons of Tertiary isotopic temperatures at the two sites indicate warmer waters at Site 167 than at Site 171. For the Oligocene and Neogene, the temperature differences are consistent with the plate motion model in which Site 167 has been nearer to the equator than Site 171. During this time interval, Site 171 moved from about $10^{\circ} \mathrm{N}$ to its present-day latitude of $19^{\circ} \mathrm{N}$.

Our data for the middle Eocene are not in as good agreement with the predictions of the simple two-phase plate motion model. The two sites are projected to have been located within $4^{\circ}$ to $6^{\circ}$ on either side of the equator at that time and therefore would be expected to indicate similar temperatures. However, the planktonic assemblage from Site 167 recorded an isotopic temperature of $22^{\circ} \mathrm{C}$ while that of Site 171 recorded a temperature of $19.5^{\circ} \mathrm{C}$. This difference of $2.5^{\circ} \mathrm{C}$ is probably larger than the uncertainty introduced into the comparison by selective solution and analytical error. The results may therefore indicate that plate motion had a higher rate of northward shift prior to 30 million years ago than has been estimated in the model we have used. In that case, Site 167 may have been north of the equator during middle Eocene time. Overall, however, the climatic histories at Sites 167 and 171 , as recorded in the $018 / 016$ ratios of mixed species of planktonic foraminifera from latest Cretaceous and late Tertiary, are in good agreement with a model of Pacific plate motion, which indicates a northward shift on the order of $30^{\circ}$ latitude over the last 100 m.y.

\section{Carbon Isotope Ratios}

Carbon isotope ratios of assemblages of planktonic and benthonic foraminifera from Sites 167 and 171 are shown plotted as a function of age in Figure 8. Also shown are carbon isotopic data from Leg 6 samples (Douglas and Savin, 1971). The total range of variation of $\mathrm{C}^{13} / \mathrm{C}^{12}$ ratios of all these samples is from -0.5 per mil to +3.9 per mil relative to the PDB standard.

Although there are some exceptions, $\mathrm{C}^{13} / \mathrm{C}^{12}$ ratios of planktonic assemblages of the same age from different cores tend to be similar. Curves drawn connecting the data from either Site 167 or 171 bear some resemblance to the oxygen isotope curves shown in Figure $5 . \mathrm{C}^{13} / \mathrm{C}^{12}$ ratios 


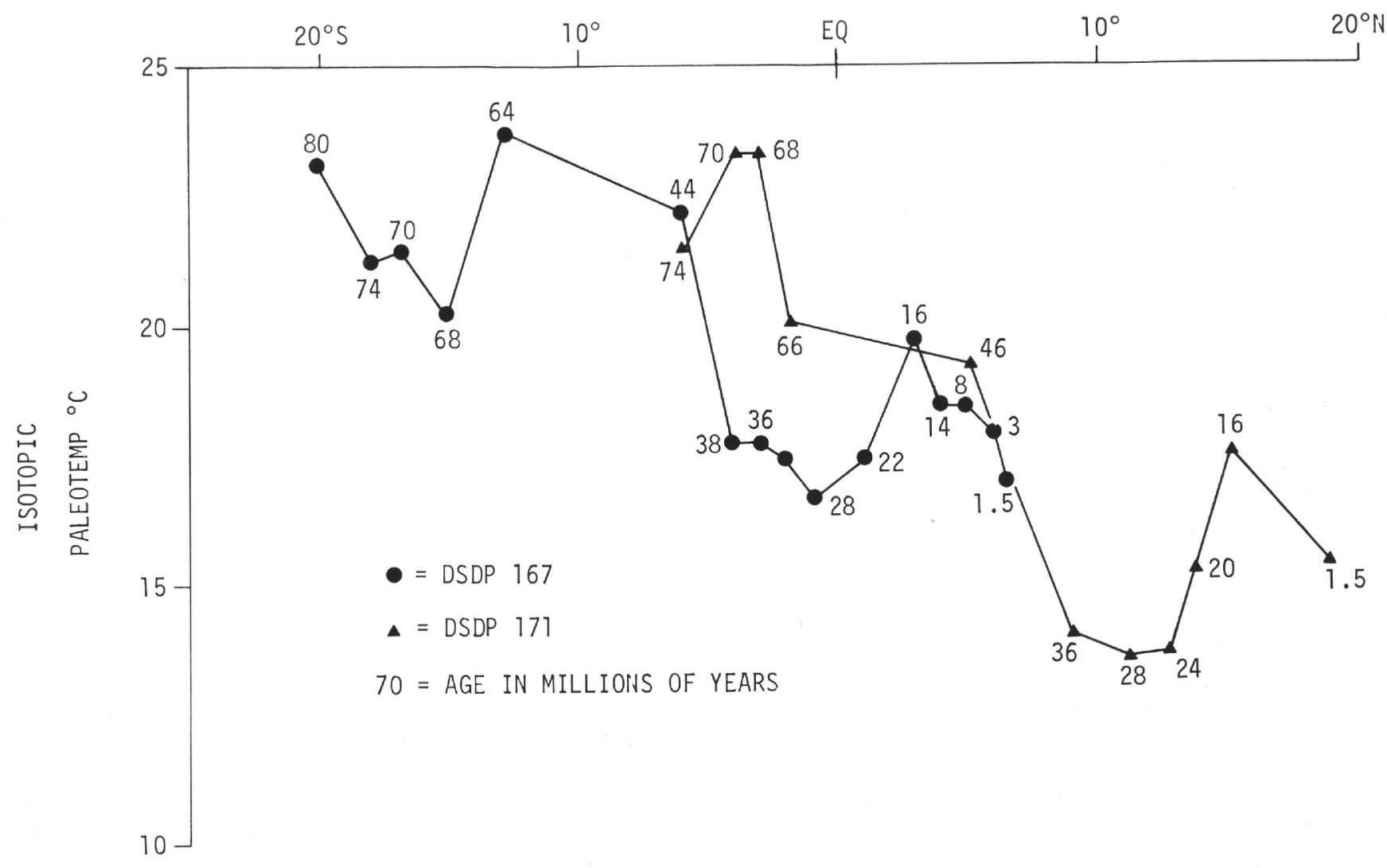

Figure 6. Isotopic paleotemperatures of planktonic assemblages at various paleolatitudinal positions of Sites 167 and 171 for the last 80 m.y. (Paleolatitudes were determined using the plate motion of Claque and Jarrard [in press]. Numbers next to data points indicate age in millions of years. For example, 64 m.y. ago Site 167 was about $11^{\circ} \mathrm{S}$, and planktonic foraminifera indicate a water temperature of about $23.6^{\circ} \mathrm{C}$.)

declined in the late Cretaceous and then rose near the boundary between the Cretaceous and the Tertiary. Another drop in $\mathrm{C}^{13} / \mathrm{C}^{12}$ ratios occurred during the Eocene and Oligocene and was followed by a rise during the early Miocene. $\mathrm{C}^{13} / \mathrm{C}^{12}$ ratios remained rather steady through the remainder of the Miocene and dropped again during the Pliocene and Pleistocene.

The $\mathrm{C}^{13} / \mathrm{C}^{12}$ ratios of benthonic assemblages are lower than those of planktonic assemblages of the same age. The difference between the $\mathrm{C}^{13} / \mathrm{C}^{12}$ ratios of benthonic and planktonic assemblages from the same sample is usually about one per mil. The variation of carbon isotope ratios of benthonic assemblages as a function of time is similar to the variations observed for planktonic assemblages.

The carbon isotope ratios of the tests of foraminifera vary not only in response to growth temperature but also as the result of variations in the $\mathrm{C}^{13} / \mathrm{C}^{12}$ ratios of dissolved and perhaps particulate carbon. In addition, $\mathrm{C}^{13 / \mathrm{C}^{12}}$ ratios may reflect biological (nonequilibrium) isotopic fractionation during secretion of the tests. The equilibrium isotopic fractionation between calcium carbonate and dissolved bicarbonate ion has a temperature coefficient of only 0.035 per mil per ${ }^{\circ} \mathrm{C}$ (Emrich et al., 1970) which by itself is too small to account for most of the observed range of carbon isotope ratios. Thus, most of the observed isotopic variation must reflect variations through time of the $\mathrm{C}^{13 / \mathrm{C}^{12}}$ ratio of oceanic carbon and of the magnitude of the biological isotopic fractionations. When the relative magnitudes of these two effects have been determined, the $\mathrm{C}^{13} / \mathrm{C}^{12}$ ratios of foraminifera from deep-sea cores may provide information on the temporal and spatial variations of $\mathrm{C}^{13} / \mathrm{C}^{12}$ ratios of dissolved carbon in the oceans.

\section{ACKNOWLEDGMENTS}

Financial support for isotopic analyses was provided by NSF Grants GA 31622 and GA 16827 and by the Marathon Oil Company. The authors wish to thank Mrs. Eva Topfl, Miss Elizabeth Kurowski, and Mr. Joseph Durazzi for their aid in preparation of the samples used for analysis.

\section{REFERENCES}

Berger, W., 1969. Ecologic patterns of living planktonic foraminifera: Deep-Sea Res., v. 16, p. 1.

Berger, W. H., 1971. Sedimentation of planktonic foraminifera: Mar. Geol., v. 11, p. 325-358.

Berggren, W. A., 1969. Rates of evolution in some Cenozoic planktonic foraminifera: Micropaleontology, v. 15, p. 351.

Berggren, W. A., 1972. A cenozoic time scale-Some implications for regional geology and paleobiogeography: Lethaia, v. 5, p. 195-205.

Clague, D. A. and Jarrard, R. D., in press. Tertiary Pacific plate motion deduced from the Hawaiian Emperor chain: Geol. Soc. Am. Bull. 


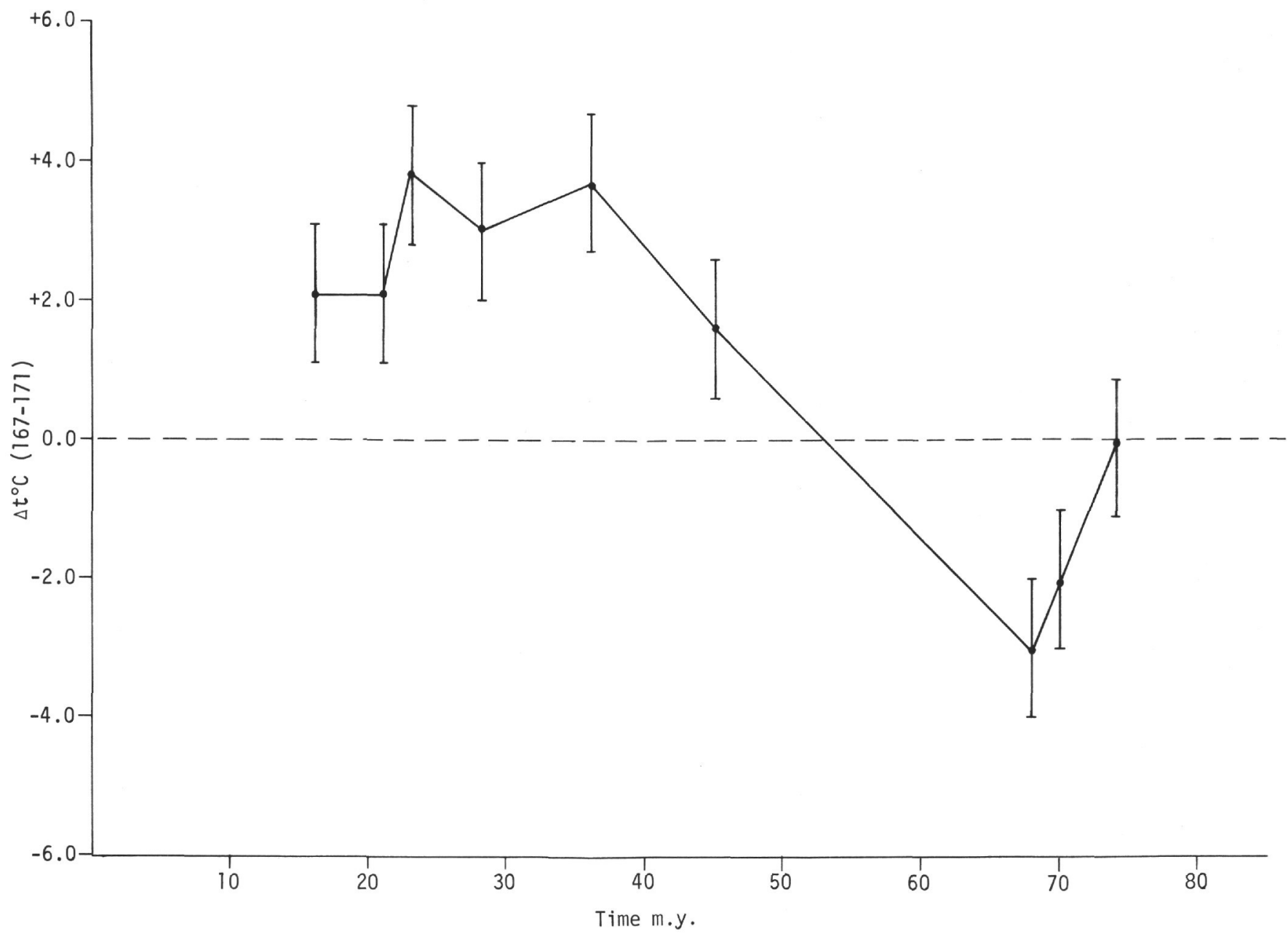

Figure 7. $\Delta \mathrm{t}$, difference between the isotopic temperatures of planktonic assemblages from Sites 167 and 171 plotted as a function of sample age.

Craig, H., 1969. The measurement of oxygen isotope paleotemperatures: Spoleto Conf. Stable Isotopes Oceanogr. Stud. Paleotemp. Proc. v. 3, p. 1.

Douglas, R. and Savin, S., 1971. Isotopic analyses of planktonic foraminifera from the Cenozoic of the Northwest Pacific, Leg 6: Initial Reports of the Deep Sea Drilling Project Volume VI. Washington (U. S. Government Printing Office), p. 1123. , 1972. Depth stratification in Tertiary and Cretaceous planktonic foraminifera: Geol. Soc. Am. Ann. Absty. Meeting.

, Depth distribution in planktonic foraminifera based on oxygen isotope analyses: J. Foram. Res. (in press).

Duplessy, J. C., Claude LaLov, C. and Vinot, A. C., 1970. Differential isotopic fractionation in benthic foraminifera and paleotemperatures reassessed: Science, v. 168, p. 250 .

Emiliani, C., 1971. Depth habitats of growth stages of pelagic foraminifera: Science, v. 173, p. 1122-1124.

Emrich, K., Ehhalt, D. H. and Vogel, J. C., 1970. Carbon isotope fractionation during the precipitation of calcium carbonate: Earth Planet. Sci. Letí. v. 8, p. 363-371.
Epstein, S., Buchsbaum, R., Lowenstein, H. and Urey, H., 1951. Carbonate-water isotopic temperature scale: Geol. Soc. Am. Bull., v. 62, p. 417.

Ewing, J., Ewing, M., Aitken, T. and Ludwig, W. J., 1968. North Pacific sediment layers measured by seismic profiling. In The Crust and Upper Mantle of the Pacific Area: Geophys. Monogr. 12, Washington, Am. Geophys. Union, p. 147.

Francheteau, J., Harrison, C. G. A., Sclatter, J. G. and Richards, M. L., 1970. Magnetization of Pacific seamounts: a preliminary polar curve for the northeastern Pacific: J. Geophys. Res. v. 75, p. 2035.

Hays, J. D., Cook, H., Cook, F., Fuller, J., Jenkins, D. G., Goll, R., Milo, D. and Orr, W., 1970. Deep-Sea Drilling Project, Leg 9: Geotimes, April 1970, p. 11.

Hecht, A., 1971. Morphologic variation diversity and stable isotope geochemistry of recent planktonic foraminifera from the North Atlantic: Ph.D. Dissertation, Case Western Reserve University.

Lidz, B., Kehm, A. and Miller, H., 1968. Depth habitats of pelagic foraminifera during the pleistocene: Nature, $v$. 217 , p. $245-247$. 


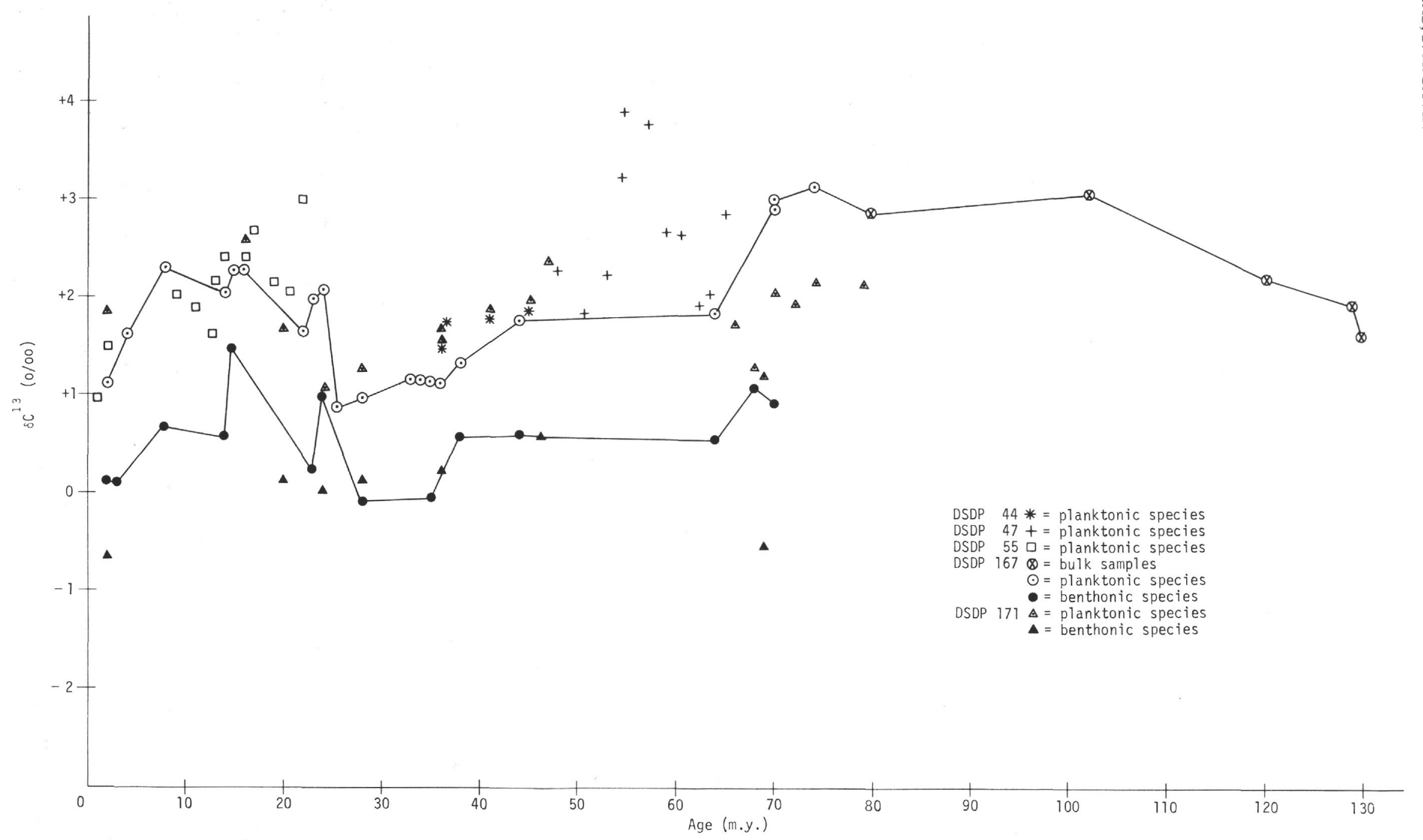

Figure 8. Carbon isotope results from Sites 47, 55, 167, and 171 plotted as a function of sample age. 
Saito, T. and Van Donk J., 1971. Oxygen isotopic measurements of Late Cretaceous sediments: Geol. Soc. Am. Abstr. Ann. Meeting v. 3, p. 692.

Savin, S. and Douglas, R. Stable isotope and Magnesium Geochemistry of Recent planktonic foraminifera from the South Pacific: Geol. Soc. Am. Bull. (in press).

Sclater, J. G. and Jarrard, R. D., 1971. Preliminary paleomagnetic results, Leg 7. Initial Reports of the Deep Sea Drilling Project, Volume VII. Washington (U. S. Government Printing Office), 1227 .

Tracey, J. I., Jr., Sutton, G. H., Galehouse, J. S., Nesteroff, W. D., von der Borch, C., Beckman, J. P., Hag, U. Z. B.,
Lipps, J. H. and Moore, T. C., 1971. Initial Reports of the Deep Sea Drilling Project, Volume VIII. Washington (U. S. Government Printing Office), 1037 p.

van Andel, T. H., Heath, G. R., Bennett, R. H., Charleston, S., Cronan, P. S., Rodolfo, K. S., Yeats, R. S., Bukry, D., Dinkelman, M. and Kaneps, A., 1971. Deep Sea Drilling Project Leg 16: Geotimes, June 1971, p. 12.

Winterer, E. L., Riedel, W. R., Bronniman, P., Gealy, E. L., Heath, G. R., Kroenke, L., Martini, E., Moberly, R., Jr., Resig, J. and Worsley, T., 1971. Initial Reports of the Deep Sea Drilling Project, Volume VII. Washington (U. S. Government Printing Office), 1754 p. 